\title{
MOLECULAR CHARACTERIZATION OF AVIAN INFLUENZA VIRUS- H9N2 SUBTYPE FROM BROILER CHICKEN IN THE EASTERN REGION OF SAUDI ARABIA 2012 to 2014
}

\author{
ABDULLAH I.A. ALMUBARAK \\ Department of Microbiology and Parasitology, College of Veterinary Medicine, \\ King Faisal University, Saudi Arabia, Fax: 009665896617; Bo-Box: 31982
}

Received: 30 September 2018; Accepted: 28 October 2018

\begin{abstract}
Avian Influenza Virus (AIV)-H9 subtype was reported to be endemic in Asia and Middle East. It induces considerable economic losses in poultry industry and was involved in human infection. In the present study, attempts were made to estimate the RT-PCR-based prevalence of Avian Influenza Virus-H9N2 subtype in the Eastern Region of Saudi Arabia during the period from January 2012 to March 2014. Tissue samples were collected from 115 flocks of broiler chicken from targeted region during the study period. Part of the Hemagglutinin (HA) gene was directly sequenced to determine circulating genotype. Samples from four flocks were positive to AIV-H9 subtype. Sequencing and phylogenetic analysis of the four detections showed high nucleotide identity to each other and to previous AIV-H9N2 isolates from Saudi Arabia, UAE and Israel. The four detections belong to G1 lineage of the H9N2 subtype. AIV-H9 subtype seems to be of low prevalence in broiler chicken of the Eastern region of Saudi Arabia. Further studies to determine biologic and pathologic characterizations of these detections and to determine prevalence of other AIV subtypes in Saudi Arabia are required to build control and prevention strategy and to minimize the threat it pose to public health.
\end{abstract}

Key words: Avian Influenza, H9N2, Eastern Saudi Arabia, Broiler Chicken, Phylogenetic Analysis.

\section{INTRODUCTION}

Avian Influenza Viruses (AIVs) belong to the genus (or type) Influenzavirus $A$, family Orthomyxoviridae. It has a segmented, negative, single stranded RNA genome. It composed of 8 segments encoding 11 proteins (Lee et al., 2013). Two of which, Hemagglutinin (HA) and Neuraminidase (NA), represent a surface antigens and have been used in subtyping of influenza A virus into eighteen $\mathrm{H}$ subtypes and eleven $\mathrm{N}$ subtypes (Tong et al., 2013).

Infection with AIVs occurs in wide range of domestic and wild birds throughout the world. The disease occurs in two forms, highly fatal systemic infection that termed "Highly Pathogenic Avian Influenza" (HPAI) and mild infection that termed "Low Pathogenic Avian Influenza" (LPAI) (Saif et $a l ., 2008)$. All HPAI viruses belong to $\mathrm{H} 5$ and $\mathrm{H} 7$ subtypes despite the fact that majority of the $\mathrm{H} 5$ and $\mathrm{H} 7$ isolates belong to LPAI. H9N2 AIV subtype is an important LPAI with widespread in domestic fowls (Iqbal et al., 2013; O.I.E., 2014).

Corresponding author: Dr. ABDULLAH I.A. ALMUBARAK

E-mail address: aialsheikhmubarak@gmail.com

Present address: Department of Microbiology and Parasitology, College of Veterinary Medicine, King Faisal University, Saudi Arabia, Fax: 009665896617; Bo-Box: 31982
AIV-H9N2 subtype was first isolated from turkey in the united states in 1966 (Homme and Easterday, 1970). It spread and became established in domestic poultry at the mid 1990s. Thereafter, virus has become endemic in Asia and Middle East including Saudi Arabia, United Arab of Emirates, Jordan, Lebanon, Egypt, Iran and Pakistan (Al-Natour and Abo-Shehada, 2005; Fusaro et al., 2011; Kayali et al., 2013). H9N2-induced outbreaks were also reported in Europe, Africa and USA (Alexander, 2000; Fusaro et al., 2011). H9N2 was also reported to be the most prevalent subtype of AIVs in China, where it was linked to severe economic impact on poultry industry (Sun and Liu, 2015).

Two major lineages of AIV-H9N2 were previously recognized, the Eurasian and the North American. The Eurasian AIV-H9N2 major lineage further divided into three minor lineages including: (I) G1 lineage corresponding to the prototype isolate A/Quail/Hong Kong/G1/97; (II) Y280 lineage corresponding to three prototype isolates A/duck/Hong Kong/Y280/97, A/Chicken/Beijing/ 1/94, and A/Chicken/Hong Kong/G9/97. Alternatively, the Y280 lineage termed BJ94 or G9 lineage. (III)Y439 (or Korean) lineage represented by two prototype isolates A/chicken/Korea/38349p96323/96, and A/duck/Hong Kong/Y439/97 (Butt et al., 2010). 
The present study aimed to assess the role played by AIV-H9N2 subtype in respiratory infections of the broiler chicken of in the Eastern Region of Saudi Arabia as well as to determine the circulating genotype of this virus. Attempt was also made to deduce mutational changes occurred over the sequenced part of HA gene from the H9-viruses reported from targeted region over the past 20 years.

\section{MATERIALS AND METHODS}

\section{Sample collection and processing}

Tissue samples, including trachea and lung, were collected from broiler chicken in the eastern region of Saudi Arabia during the period from January 2012 to March 2014. Broilers with signs of respiratory infection were targeted. Samples were collected in 10 volumes phosphate buffered saline containing gentamicin and nystatin at a concentration of $50 \mu \mathrm{g}$ of each/ml, and stored in $80^{\circ} \mathrm{C}$ until homogenized. Homogenization was performed with Biospec- MiniBeadbeater and Omni International Ceramic Beads Kit. IQeasy Plus Viral DNA/RNA Extraction Kit (Cat \# 17153, iNtRON Biotechnology, South Korea) was used, according to manufacturer instructions, to extract viral RNA from homogenized tissues. Extracted RNA was stored in $80^{\circ} \mathrm{C}$ until used to produce cDNA by Reverse Transcription System (Cat \# A3500, Promega, USA) according to manufacturer instructions.

\section{Detection and genotyping $R T-P C R$}

HU1c and HU2 primer (shown in table 1) that previously described by (Banks et al., 2000) and target HA gene of H9 subtype was used for detection and genotyping of AIV H9 subtype. For genotyping, i-StarMAX II (Cat \# 25174, iNtRON biotechnology, South Korea) in a final volume of $50 \mu$ l was used. The PCR product was purified using Wizard SV Gel and PCR Clean-up System (Cat \# A1460, Promega, USA) according to manufacturer instructions. Purified amplicons were sequenced by Macrogen Sequencing Service (South Korea).

\section{Sequence analysis}

Sequence analysis was performed using Molecular Evolutionary Genetic Analysis (MEGA) X software (Kumar et al., 2018). Sequences were trimmed to 432 nucleotides corresponding to the region flanked by nucleotides 603 and 1034 of the strain A/CK/SA/C-36362/2010 (GenBank access \# JX273557). BLAST search was performed to determine the most related sequence in GenBank. Three representative poultry prototypes as well as sequences from Saudi Arabia and surrounding region were included in phylogenetic analysis and used to infer the origin of the present four detections (Figure 1 and Table 2). Over the sequenced area, amino acids was deduced and compared with amino acid sequences of $\mathrm{H} 9 \mathrm{~N} 2$ isolates retrieved from gulf area and deposited in genbank (table 3).

\section{Genbank accession number}

Sequences obtained from the present four detections of AIV-H9 subtype were deposited in Genbank with the following accession number: MK123384 for A/Chicken/SA/AC72/13, MK123385 for A/Chicken/ SA/AC9/13, MK123386 for A/Chicken/ SA/AH21/13 and MK123387 for A/Chicken/ SA/AH29/13.

Table 1: Shows the used primer sequence and annealing temperature for the used RT-PCR to detect and genotype AIV-H9 subtype. Adapted from (Banks et al., 2000). 


\section{RESULTS}

\section{Prevalence and Genotyping of AIV-H9N2 subtype}

During the period from January 2012 to March 2014, a total of 115 flocks of broiler chicken were sampled. Four flocks (3.5\%) were positive to AIVH9 subtype using RT-PCR that targets HA gene. Sequencing and phylogenetic analysis of these four detections showed that it belongs to the G1 lineage as in figure 1. A/Chicken/SA/AH21/13 and A/Chicken/SA/AH29/13 were almost identical (99.8\% nucleotide similarity). These two isolates share, respectively, $98.8 \%$ and $99.1 \%$ nucleotide similarity with the third isolate A/Chicken/ $\mathrm{SA} / \mathrm{AC} 72 / 13$. All of these isolates showed a lower degree of similarity with the fourth isolate $\mathrm{A} /$ Chicken/SA/AC9/13 as shown in table 2. Blast search relabeled that the old Saudi isolate $\mathrm{A} / \mathrm{CK} / \mathrm{SA} / \mathrm{C}-36362 / 2010$ (GB\# JX273557.1) is the most similar to A/Chicken/SA/AC9/13with $99.1 \%$ nucleotide identity. On the other hand, A/Chicken/ Saudi Arabia/16/2015 (GB\# MG051077.1) was the most similar to AH29/13 and AC72/13 with $97.9 \%$ nucleotide identities and to $\mathrm{AH} 21 / 13$ with $97.7 \%$ nucleotide identity.

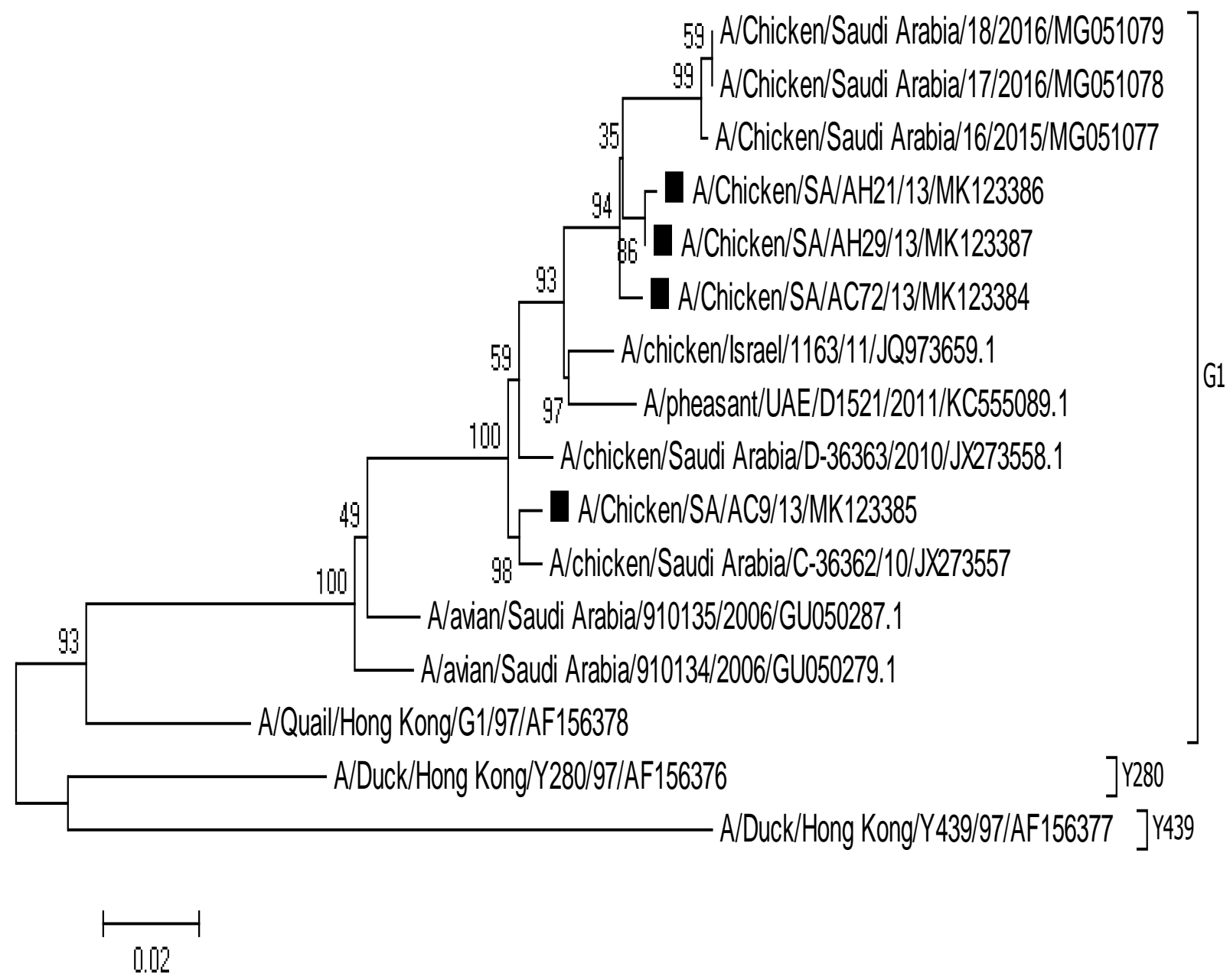

Figure 1: Phylogenetic tree, based on partial HA gene sequence, showing relatedness of the present Saudi AIVH9 detections (tagged with black square) and reference sequences from lineages of H9N2 subtype including locally and regionally circulating strains. Genbank access numbers are shown after strain name. 
Table 2: Nucleotide identity of partial HA gene sequence of the present four Saudi AIV-H9N2 detections together with local/regional reference sequences from lineages of H9N2 subtype. Genbank access numbers are shown in brackets.

\begin{tabular}{|c|c|c|c|c|c|c|c|c|c|c|c|c|c|c|}
\hline & Sequences (Genbank access number) & 1 & 2 & 3 & 4 & 5 & 6 & 7 & 8 & 9 & 10 & 11 & 12 & 13 \\
\hline 1 & A/Chicken/SA/AH21/13(MK123386) & & & & & & & & & & & & & \\
\hline 2 & A/Chicken/SA/AH29/13(MK123387) & 99.8 & & & & & & & & & & & & \\
\hline 3 & A/Chicken/SA/AC72/13(MK123384) & 98.8 & 99.1 & & & & & & & & & & & \\
\hline 4 & A/Chicken/SA/AC9/13(MK123385) & 96.3 & 96.5 & 97.0 & & & & & & & & & & \\
\hline 5 & A/Chicken/Saudi_Arabia/16/2015(MG051077) & 97.7 & 97.9 & 97.9 & 95.4 & & & & & & & & & \\
\hline 6 & A/chicken/Israel/1163/11(JQ973659.1) & 97.2 & 97.5 & 97.5 & 97.2 & 96.3 & & & & & & & & \\
\hline 7 & A/avian/Saudi_Arabia/910135/2006(GU050287.1) & 93.5 & 93.8 & 94.2 & 95.4 & 92.6 & 94.0 & & & & & & & \\
\hline 8 & $\begin{array}{l}\text { A/chicken/Saudi_Arabia/D- } \\
\text { 36363/2010(JX273558.1) }\end{array}$ & 96.5 & 96.8 & 96.8 & 98.4 & 95.6 & 97.5 & 95.1 & & & & & & \\
\hline 9 & A/avian/Saudi_Arabia/910134/2006(GU050279.1) & 93.3 & 93.5 & 94.0 & 95.1 & 92.4 & 94.2 & 97.5 & 94.9 & & & & & \\
\hline 10 & A/pheasant/UAE/D1521/2011(KC555089.1) & 96.8 & 97.0 & 97.0 & 96.8 & 95.8 & 97.7 & 93.5 & 97.0 & 94.2 & & & & \\
\hline 11 & A/chicken/Saudi_Arabia/C-36362/10(JX273557) & 96.3 & 96.5 & 97.0 & 99.1 & 95.4 & 97.2 & 95.4 & 98.4 & 95.1 & 96.8 & & & \\
\hline 12 & A/Quail/Hong_Kong/G1/97(AF156378) & 86.3 & 86.6 & 86.8 & 87.7 & 85.6 & 86.8 & 90.5 & 87.5 & 90.3 & 86.1 & 88.2 & & \\
\hline 13 & A/Duck/Hong_Kong/Y280/97(AF156376) & 83.8 & 84.0 & 84.0 & 84.5 & 82.9 & 84.0 & 87.3 & 84.5 & 87.7 & 83.6 & 85.0 & 89.6 & \\
\hline 14 & A/Duck/Hong_Kong/Y439/97(AF156377) & 80.3 & 80.6 & 80.3 & 80.3 & 79.9 & 80.3 & 81.7 & 80.8 & 81.9 & 81.0 & 80.8 & 83.8 & 83.1 \\
\hline
\end{tabular}

\section{Analysis of deduced amino acid}

Sequenced region of the HA gene from the present Saudi detections were trimmed to 432 nucleotides (nt. 571 to 1002 according to HA gene of the strain A/Quail/Hong Kong/G1/97, GenBank access \# AF156378.1). A segment of 144 amino acids (191334) were deduced. This region contains part of the receptor binding site and relevant glycosylation sites. The four detections were completely identical over deduced amino acids except one difference at position 282, where Serine (S) present in A/Chicken /SA/AC9/13 while Asparagine $(\mathrm{N})$ present in the other three detections. When compared with A/Quail /Hong Kong/G1/97, G1 prototype of the AIV-H9 subtype, 18 amino acid substitutions were found in this segment with no insertion/deletion mutation.

\section{Analysis of the amino acids at Receptor Binding Site $(\mathrm{RBS})$}

Amino acid residues at receptor binding site of the present detections were compared with that of A/Quail/Hong Kong/G1/97 as shown in table 3.
Residues at position 191, 197, 202, 203, 232, 234, 236 and 237 remain conserved, while change from Glutamic acid to Alanine at position 198, from Aspartic acid to Glycine at position 233 and from Glutamine to Isoleucine at position 235 were occurred.

Extending the comparison to previous sequences retrieved from gulf area showed that other substitutions Threonine, Isoleucine, Valine have occurred at position 198. Similarly, other substitutions occurred at position 235 including Methionine, Leucine, Threonine, Phenylalanine as shown in table 3 .

\section{Glycosylation motifs}

Over sequenced region, two glycosylation N-X-T/S motifs (Where $\mathrm{N}=$ Aspragine, $\mathrm{X}=$ any amino acid except Proline, $\mathrm{T}=$ Threonine, $\mathrm{S}=$ Serine) were found at positions 298-300 and 305-307 while two motifs at positions 206-208 and 218-220 were lost. The former lost due to substitution of Asparagine to Threonine at position 206, while the latter lost due to substitution of Asparagine to Aspartic acid at position 218 
Table 3: Comparison of some HA amino acids between the present Saudi detections and earlier detections reported by previous studies from gulf area. Only amino acids relevant to receptor binding are shown.

\begin{tabular}{|c|c|c|c|c|c|c|c|c|c|c|c|c|}
\hline \multirow{2}{*}{$\begin{array}{l}\text { Name of isolate } \\
\text { Number of a } \\
\text { A/Quail/Hong Ko } \\
\text { AF156378 }\end{array}$} & \multicolumn{2}{|l|}{$\begin{array}{l}\text { Genbank } \\
\text { access \# }\end{array}$} & \multicolumn{5}{|c|}{ Receptor Binding Site } & \multirow{2}{*}{$\begin{array}{l}\begin{array}{l}\text { Receptor } \\
\text { left pocket }\end{array} \\
232-237 \\
\end{array}$} & \multicolumn{4}{|c|}{ Glycosylation motifs } \\
\hline & $\begin{array}{l}\text { according to } \\
\text { bank access \# }\end{array}$ & 191 & 197 & 198 & 201 & 202 & 203 & & $\begin{array}{l}206- \\
208\end{array}$ & $\begin{array}{l}218- \\
220\end{array}$ & $\begin{array}{l}298- \\
300\end{array}$ & $\begin{array}{l}305- \\
307\end{array}$ \\
\hline $\begin{array}{l}\text { H3 numbering according to Kan } \\
\text { (2014) }\end{array}$ & leil and others & 183 & 189 & 190 & 193 & 194 & 295 & $224-229$ & $\begin{array}{l}198- \\
200\end{array}$ & $\begin{array}{l}210- \\
212 \\
\end{array}$ & $\begin{array}{l}290- \\
292 \\
\end{array}$ & $\begin{array}{l}297- \\
299\end{array}$ \\
\hline A/Quail/Hong Kong/G1/97 & AF156378 & $\mathrm{H}$ & $\mathrm{T}$ & $\mathrm{E}$ & $\mathrm{N}$ & $\mathrm{L}$ & $\mathrm{Y}$ & NDLQGR & NDT & NRT & NST & NIS \\
\hline $\begin{array}{l}\text { A/chicken/Saudi } \\
\text { Arabia/CP7/1998 }\end{array}$ & CY081264.1 & . & . & . & $\mathrm{S}$ & . & . & NGQQGR & TDT & NRI & NST & NIS \\
\hline $\begin{array}{l}\text { A/chicken/United Arab } \\
\text { Emirates/AG537/99 }\end{array}$ & AJ781824.1 & . & . & $\mathrm{A}$ & . & . & . & NGQQGR & TDT & NRT & NST & NIS \\
\hline $\begin{array}{l}\text { A/chicken/Saudi } \\
\text { Arabia/AG516/2000 }\end{array}$ & AJ781826.1 & . & . & A & . & . & . & NGLQGR & TDT & NRI & NST & NIS \\
\hline A/quail/Dubai/301/2000 & EF063510.1 & . & . & . & . & . & . & NGLQGR & TDT & NRT & NST & NIS \\
\hline A/quail/Dubai/303/2000 & EF063512.1 & . & . & $\mathrm{A}$ & $\mathrm{D}$ & . & . & NGQQGR & TDT & NRT & NST & NIS \\
\hline A/chicken/Dubai/339/2001 & KF188352.1 & . & . & A & . & . & . & NGLMGR & TDT & NRT & NST & NIS \\
\hline A/chicken/Emirates/R66/2002 & CY076723.1 & . & . & . & . & . & . & NGQLGR & TDT & NRT & NST & NIS \\
\hline $\begin{array}{l}\text { A/chicken/Saudi Arabia/EPD- } \\
\text { 22-01/2002 }\end{array}$ & GU050554.1 & . & . & $\mathrm{A}$ & . & . & . & NGLQGR & TDT & NMI & NST & NIS \\
\hline A/chicken/Dubai/463/2003 & EF063516.1 & . & . & A & . & . & . & NGLLGR & TDT & NRT & NST & NIS \\
\hline A/chicken/Kuwait/9/2004 & JX273545.1 & . & . & A & . & . & . & NGLIGR & TDT & DRT & NST & NIS \\
\hline $\begin{array}{l}\text { A/stone curlew/United Arab } \\
\text { Emirates/1147/2005 }\end{array}$ & KF188337.1 & . & . & $\mathrm{T}$ & . & . & . & NGQIGR & TDT & DRT & NST & NVS \\
\hline $\begin{array}{l}\text { A/stone curlew/United Arab } \\
\text { Emirates/1127.3/2005 }\end{array}$ & KF188371.1 & . & . & $\mathrm{V}$ & . & . & . & NGQIGR & TNT & DRT & NST & NVS \\
\hline $\begin{array}{l}\text { A/white bellied bustard/ United } \\
\text { Arab Emirates/ 1036/2005 }\end{array}$ & KF188236.1 & . & . & A & . & . & . & NGQTGR & TNT & DRT & NST & NVS \\
\hline $\begin{array}{l}\text { A/white bellied bustard/ United } \\
\text { Arab Emirates /1127.1/2005 }\end{array}$ & KF188244.1 & . & . & A & . & . & . & NGQIGR & TDT & DRT & NST & NVS \\
\hline $\begin{array}{l}\text { A/white bellied bustard/ United } \\
\text { Arab Emirates/1019/2005 }\end{array}$ & KF188258.1 &. & . & $\mathrm{A}$ & . & . & . & NGQTGR & TDT & DRT & NST & NVS \\
\hline $\begin{array}{l}\text { A/quail/United Arab Emirates } \\
/ 1136 / 2005\end{array}$ & KF188254.1 & . & . & A & . & . & . & NDQTGR & NDT & DRT & NST & NVS \\
\hline $\begin{array}{l}\text { A/chicken/Saudi Arabia/ 582/ } \\
2005\end{array}$ & JX273556.1 & . & . & $\mathrm{T}$ & . & . & . & NGLIGR & TDT & DRT & NST & NIS \\
\hline $\begin{array}{l}\text { A/avian/Saudi Arabia/ 910135/ } \\
2006\end{array}$ & GU050287.1 & . & . & $\mathrm{A}$ & . & . & . & NGLIGR & TDT & DRT & NST & NIS \\
\hline $\begin{array}{l}\text { A/avian/Saudi Arabia/ 910136/ } \\
2006\end{array}$ & GU050295.1 & . & . & $\mathrm{T}$ & . & . & . & NGLIGR & TDT & DRT & NST & NIS \\
\hline $\begin{array}{l}\text { A/chicken/Saudi Arabia/E- } \\
36364 / 2006\end{array}$ & JX273559.1 & . & . & $\mathrm{V}$ & . & . & . & NGLIGR & TDT & DRT & NST & NIS \\
\hline $\begin{array}{l}\text { A/houbara/United Arab } \\
\text { Emirates/78/2006 }\end{array}$ & KF188329.1 & . & . & $\mathrm{T}$ & . & . & . & NGLFGR & TDT & DRT & NST & NIS \\
\hline $\begin{array}{l}\text { A/falcon/United Arab } \\
\text { Emirates/897/2007 }\end{array}$ & KF188240.1 & . & $\mathrm{S}$ & $\mathrm{I}$ & $\mathrm{D}$ & . & . & NGQIGR & NDT & DRT & NST & NVS \\
\hline $\begin{array}{l}\text { A/chicken/United Arab } \\
\text { Emirates/F1P7/2011 }\end{array}$ & JX273562.1 & . & . & $\mathrm{A}$ & . & . & . & NGLLGR & TDT & DRT & NST & NIS \\
\hline $\begin{array}{l}\text { A/white bellied bustard/ United } \\
\text { Arab Emirates/ D1520/2011 }\end{array}$ & KC555081.1 & . & . & $\mathrm{V}$ & . & . & . & NGLFGR & TDT & DRT & NST & NIS \\
\hline $\begin{array}{l}\text { A/quail/United Arab Emirates } \\
\text { /D1556/2011 }\end{array}$ & KC555097.1 & . & $\mathrm{S}$ & $\mathrm{I}$ & $\mathrm{Q}$ & . & . & NGQFGR & NDT & DRT & NST & NVS \\
\hline A/Chicken/SA/AH21/13 & MK123386 & . & . & A & . & . & . & NGLIGR & TDT & DRT & NST & NIS \\
\hline A/Chicken/SA/AH29/13 & MK123387 & . & . & A & . & . & . & NGLIGR & TDT & DRT & NST & NIS \\
\hline A/Chicken/SA/AC72/13 & MK123384 & . & . & A & . & . & . & NGLIGR & TDT & DRT & NST & NIS \\
\hline A/Chicken/SA/AC9/13 & MK123385 & . & . & $\mathrm{A}$ & . & . & . & NGLIGR & TDT & DRT & NST & NIS \\
\hline
\end{tabular}




\section{DISCUSSION}

Avian influenza viruses receive increasing attention because of its zoonotic nature and transmission mode. Transmission of AIV-H9 subtype to human has been previous reported (Wan et al., 2008). Little is known about this virus in Saudi Arabia and surrounding countries. The present study tried to document the prevalence and circulating genotypes of AIV-H9N2 subtype in the Eastern Region of Saudi Arabia. A prevalence of $3.5 \%$ (4 out of 115 samples) was found in targeted area. A previous study conducted in Northern Region of Saudi Arabia showed higher detection rate $(21 \%)$. In that study, the rate was calculated based on birds level and involved broiler and layer chicken (Alkhalaf, 2010). Similarly, detection rates of $16 \%$ was reported in Iraq (Kraidi et al., 2017), 17.4\% in Egypt (Shalaby et al., 2014) 12\% (Ahmed et al., 2009) and $8.3 \%$ in Pakistan (Kausar et al., 2018).

Lower detection rates are expected as the samples collected regardless of their disease status. In this way, samples were collected from 3583 birds from healthy and diseased chicken, duck geese and turkeys in south Egypt during 2009 to 2011. Only seven samples were positive to H9 subtype (Osman et al., 2015). Several other factors may also affect prevalence of H9 subtype including: (1) effectiveness of control measures in the targeted farms; (2) location of the targeted farms on the way of migratory birds (Al-Natour and Abo-Shehada, 2005); (3) the occurrence of simultaneous or previous H9 outbreak; (4) application of AIV-H9 live vaccines (Kayali et al., 2014). In Saudi Arabia, only killed H9 vaccine is available (C.F.S.P.H., 2015).

Phylogenetic analysis and Blast search for the present HA gene nucleotide sequence revealed that the current Saudi AIV-H9 detections were closely related to previously reported sequences from Saudi Arabia, United Arab of Emirates (UAE) and Israel including A/CK/SA/C-36362/2010 (GB\# JX273557.1), A/pheasant/ UAE/D1521/2011 (GB\# KC555089.1) and A/chicken/Israel/1163/11 (GB\# JQ973659.1) respectively. Pathogenicity study on similar isolate from UAE failed to induce clinical disease; however, coincidence with other respiratory disease, such as infectious bronchitis, was reported to produce significant disease in poultry (Aamir et al., 2007).

Failure of H9N2 subtype to induce clinical signs may help infection gone unnoticed. In such cases, relevant measures to protect public health may not be taken, thus, increasing the possibility of transmission to human. In this regards, previous studies suggest the involvement of some poultry species in transmission of AIV from aquatic fowls to humans (Arafa et al., 2012). Crossing the species barrier may facilitate reassortment of this virus with other highly pathogenic AIVs and allow them to transmit from human to human (Wan et al., 2008; Homayounimehr et al., 2010). For instance, reassortment with $\mathrm{H} 5$ and $\mathrm{H} 9$ subtypes was reported previously. Reports showed that the H5N1 involved in 1997 Hong Kong outbreak of avian flu in human to harbor six internal genes from H9N2 subtype, G1 lineage AIV (Guan et al., 1999).

Comparing deduced amino acid from the present sequences with those previously reported from gulf area showed occurrence of several substitutions during period from 1998 to 2013, which may affect virulence and host tropism. Previous studies demonstrated that substitution of certain amino acid residues at receptor binding sites of the hemagglutinin can alter binding specificity and host tropism. Particularly this includes positions 183/191, 190/198 and 226/234 of hemagglutinin (according to H3/H9 numbering) which contain respectively Histidine, Glutamic acid, and Glutamine residues, in AIV-H9 viruses recovered from avian species (Matrosovich et al., 2001; Wan et al., 2008).

The present detections showed the amino acid residue Leucine at position 226/234 of the hemagglutinin. Previous detections reported from gulf area showed Leucine or Glutamine residues at this position. It has been shown that amino acid substitution from Glutamine to Leucine at position 226/234 results in change of host tropism. Hemagglutinin with Glutamine at position 226/234 showed ability to bind with avian receptor sialic acid $\alpha$ 2,3 Galactose linkage (Baigent and McCauley, 2003). On the other hand, the presence of Leucine at this position permit binding of hemagglutinin to sialic acid $\alpha$ 2,6 Galactose linkage, allowing infection of human. Furthermore, Leucine at 226/234 was reported to increase magnitude of virus replication up to 100 folds in human cells infected in vitro (Wan and Perez, 2007). Experiments in ferrets showed that this substitution was also important for virus transmission and replication (Wan et al., 2008). Serine at position 228 was associated with Leucine-226 in viruses with human tropism, while Glycine at position 228 was associated with Glutamine-226 in viruses with avian tropism (Baigent and McCauley, 2003).

Amino acid residue at position 198 of hemagglutinin was also reported to affect affinity of binding to host receptor. The presence of Glutamic acid at position 198 was shown to associate with viruses from avian species and with binding affinity to sialic acid $\alpha-2,3$ Galactose linkage. Human receptor with sialic acid $\alpha$ 
2,6 Galactose linkage, showed high affinity to the hemagglutinin with Valine at position 198, and intermediate affinity to hemagglutinin with Tyrosine at position 198 and weak affinity to hemagglutinin with Alanine at position 198 (Matrosovich et al., 2001).

When compared with previous H9-HA sequences reported from gulf area, the present sequences possess two glycosylation motifs (N-X-T/S) at positions 298 and 305 while two other motifs at positions 206, 218 were lost. Previous studies showed that alteration in glycosylation pattern affects specificity of receptor binding, virus adaptation to host and virus virulence (Kandeil et al., 2014).

In conclusion, four AIV-H9N2 viruses were detected in broiler chicken in the Eastern Region of Saudi Arabia in the year 2013. The four detections showed high nucleotide similarity and all belong to G1lineage. Phylogeny demonstrates close association of the present detections with previous sequences from Saudi Arabia and United Arab of Emirates which may suggest a common source. The amino acid residues Histidine-191, Alanine-198, Leucine234, and Glycine-236 were found in receptor binding site, which may imply ability to infect both human and avian species. Complete genomic and pathologic characterization of the H9N2 subtype seems to be necessary to decide about next step in control and prevention strategy.

\section{ACKNOWLEDGMENTS}

The author thank the Deanship of Scientific Research, King Faisal University, Saudi Arabia for the financial support of this work (grant number: 150228). The authors also would like to thank Dr. Anwar Abdulwali Ghaleb for his technical support.

\section{REFERENCES}

Aamir, U.B.; Wernery, U.; Ilyushina, N. and Webster, R.G. (2007): Characterization of avian H9N2 influenza viruses from United Arab Emirates 2000 to 2003. Virology,361: 45-55.

Ahmed, A.; Khan, T.A.; Kanwal, B.; Raza, Y.; Akram, M.; Rehmani, S.F.; Lone, N.A. and Kazmi, S.U. (2009): Molecular Identification of Agents Causing Respiratory Infections in Chickens from Southern Region of Pakistan from October 2007 to February 2008. INTERNATIONAL JOURNAL OF AGRICULTURE \& BIOLOGY,11: 325-328.

Al-Natour, M.Q. and Abo-Shehada, M.N. (2005): Sero-prevalence of avian influenza among broiler-breeder flocks in Jordan. Prev Vet Med,70: 45-50.
Alexander, D.J. (2000): A review of avian influenza in different bird species. Vet Microbiol,74: 313.

Alkhalaf, A.N. (2010): Field Investigation on the Prevalence of Avian Influenza Virus Infection in Some Localities in Saudi Arabia. Pak Vet J, 30: 139-42.

Arafa, A.-S.; Hagag, N.; Erfan, A.; Mady, W.; ElHusseiny, M.; Adel, A. and Nasef, S. (2012): Complete genome characterization of avian influenza virus subtype H9N2 from a commercial quail flock in Egypt. Virus genes, 45: 283-294.

Baigent, S. J. and Mccauley, J.W. (2003): Influenza type A in humans, mammals and birds: Determinants of virus virulence, host-range and interspecies transmission. Bioessays, 25: 657-671.

Banks, J.; Speidel, E.C.; Harris, P.A. and Alexander, D.J. (2000): Phylogenetic analysis of influenza A viruses of $\mathrm{H} 9$ haemagglutinin subtype. Avian Pathol,29: 353-9.

Butt, A.; Siddique, S.; Idrees, M. and Tong, Y. (2010): Avian influenza A (H9N2): computational molecular analysis and phylogenetic characterization of viral surface proteins isolated between 1997 and 2009 from the human population. Virol J,7: 319.

C.F.S.P.H. (2015): Vaccine: Saudi Arabia [Online]. IOWA STATE UNIVERSITY. Available: http://www.cfsph.iastate.edu/Vaccines/countr y list.php?country $=121 \&$ lang $=$ en [Accessed 2015].

Fusaro, A.; Monne, I.; Salviato, A.; Valastro, V.; Schivo, A.; Amarin, N.M.; Gonzalez, C.; Ismail, M.M.; Al-Ankari, A.R.; Al-Blowi, M.H.; Khan, O.A.; Maken Ali, A.S.; Hedayati, A.; Garcia Garcia, J.; Ziay, G.M.; Shoushtari, A.; Al Qahtani, K.N.; Capua, I.; Holmes, E.C. and Cattoli, G. (2011): Phylogeography and evolutionary history of reassortant H9N2 viruses with potential human health implications. J Virol,85: 841321.

Guan, Y.; Shortridge, K.F.; Krauss, S. and Webster, R.G. (1999): Molecular characterization of H9N2 influenza viruses: were they the donors of the "internal" genes of H5N1 viruses in Hong Kong? . Proc Natl Acad Sci,96: 93639377.

Homayounimehr, A.R.; Dadras, H.; Shoushtari, A. and Pourbakhsh, S.A. (2010): Sequence and phylogenetic analysis of the haemagglutinin genes of H9N2 avian influenza viruses isolated from commercial chickens in Iran. Tropical animal health and production, 42 : 1291-1297.

Homme, P.J. and Easterday, B.C. (1970): Avian Dis, 14: 66-74. 
Iqbal, M.; Yaqub, T.; Mukhtar, N.; Shabbir, M.Z. and Mccauley, J.W. (2013): Infectivity and transmissibility of $\mathrm{H} 9 \mathrm{~N} 2$ avian influenza virus in chickens and wild terrestrial birds. Vet Res, 44: 100.

Kandeil, A.; El-Shesheny, R.; Maatouq, A.M.; Moatasim, Y.; Shehata, M.M.; Bagato, O.; Rubrum, A.; Shanmuganatham, K.; Webby, R.J. and Ali, M.A. (2014): Genetic and antigenic evolution of H9N2 avian influenza viruses circulating in Egypt between 2011 and 2013. Archives of virology, 159: 28612876.

Kausar, A.; Anwar, S.; Siddique, N.; Ahmed, S. and Dasti, J.I. (2018): Prevalence of Avian influenza H9N2 Virus among Wild and Domesticated Bird Species across Pakistan. Pakistan J. Zool., 50: 1347-1354.

Kayali, G.; Webby, R.J.; Samhouri, D.; Mafi, A.R. and Bassili, A. (2013): Influenza research in the Eastern Mediterranean Region: the current state and the way forward. Influenza Other Respir Viruses, 7: 914-21.

Kraidi, Q.A.; Langeroudi, A.G.; Madadgar, O. and Karimi, V. (2017): PREVALENCE OF AIV SUBTYPE H9 AMONG POULTRY WITH RESPIRATORY SIGNS IN IRAQ. Bulgarian Journal of Veterinary Medicine 20: 367-376.

Kumar, S.; Stecher, G.; Li, M.; Knyaz, C. and Tamura, K. (2018): MEGA X: Molecular Evolutionary Genetics Analysis across computing platforms. . Mol Biol Evol,35: 1547-1549.

Lee, D.H.; Park, J.K.; Yuk, S.S.; Erdene-Ochir, T.O.; Kwon, J.H.; Lee, J.B.; Park, S.Y.; Choi, I.S. and Song, C.S. (2013): Complete Genome Sequence of a Natural Recombinant H9N2 Influenza Virus Isolated from a WhiteFronted Goose (Anser albifrons) in South Korea. Genome Announc, 1: e00149-13.

Matrosovich, M.N.; Krauss, S. and Webster, R.G. (2001): H9N2 influenza A viruses from poultry in Asia have human virus-like receptor specificity. Virology,281: 156-162.
O.I.E. (2014): Manual of diagnostic tests and vaccines for terrestrial animals 2014 [Online]. Office international des épizooties. Available: http://www.oie.int/internationalstandard-setting/terrestrial-manual/accessonline/ [Accessed 2015].

Osman, N.; Sultan, S.; Ahmed, A.I.; Ibrahim, R.S.; Abd El-Wanes, S.A. and Ibrahim, E.M. (2015): Molecular epidemiology of avian influenza virus and incidence of $\mathrm{H} 5$ and $\mathrm{H} 9$ virus subtypes among poultry in Egypt in 2009-2011. Acta Virologica,59: 27-32.

Saif, Y.M.; Fadly, A.M.; Glisson, J.R.; Mcdougald, L.R.; Nolan, L.K. and Swayne, D.E. (2008): Diseases of poultry, Ames, Iowa, USA, Blackwell Publishing, pp.

Shalaby, A.G.; Erfan, A.M.; Abdel Reheem, F.A.; Selim, A.A.; Al Husseny, M.H.; Kholosy, S.G. and Nasef, S.A. (2014): AVIAN INFLUENZA VIRUS AND NEWCASTLE VIRUS SURVEILLANCE AND CHARACTERIZATION IN BROILER AND LAYER CHICKEN FLOCKS IN EGYPT. Assiut Vet. Med. J.,60: 100-109.

Sun, Y. and Liu, J. (2015): H9N2 influenza virus in China: a cause of concern. Protein Cell,6: 1825.

Tong, S.; Zhu, X.; Li, Y.; Shi, M.; Zhang, J.; Bourgeois, M.; Yang, H.; Chen, X.; Recuenco, S.; Gomez, J.; Chen, L.M.; Johnson, A.; Tao, Y.; Dreyfus, C.; Yu, W.; Mcbride, R.; Carney, P.J.; Gilbert, A.T.; Chang, J.; Guo, Z.; Davis, C.T.; Paulson, J.C.; Stevens, J.; Rupprecht, C.E.; Holmes, E.C.; Wilson, I.A. and Donis, R.O. (2013): New world bats harbor diverse influenza A viruses. PLoS Pathog,9: e1003657.

Wan, H. and Perez, D.R. (2007): Amino acid 226 in the hemagglutinin of H9N2 influenza viruses determines cell tropism and replication in human airway epithelial cells. Journal of virology, 81: 5181-5191.

Wan, H., Sorrell, E.M.; Song, H.; Hossain, M.J.; Ramirez-Nieto, G.; Monne, I.; Stevens, J.; Cattoli, G.; Capua, I. and Chen, L.-m. (2008): Replication and transmission of H9N2 influenza viruses in ferrets: evaluation of pandemic potential. PloS one,3: e2923. 


\title{
التوصيف الحيوي الجزيئى لفيروس انفلونزا الطيور- النمط الفرعي H9 من قطعان الاجاج اللاحم في المنطقة الثرقية

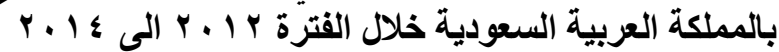

\author{
عبد الله إبراهيم ال الثيخ مبارك \\ قسم الاحياء الدقيقة و الطفيليات ـ كلية الطب البيطري - جامعة الملك فيصل ـ المملكة العربية السعودية
}

Email: aialsheikhmubarak@gmail.com Assiut University web-site: www.aun.edu.eg

تشير الدر اسات الحديثة الى ان فيروس أنفلونزا الطيور - النمط الفرعي AIV-H9 مسنوطن في فطعان الدو اجن في قارة آسيا والثرق الثرق

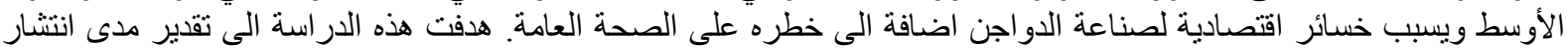

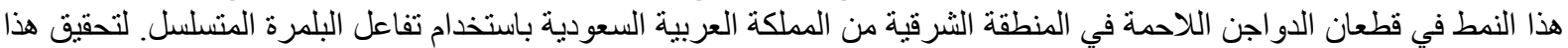

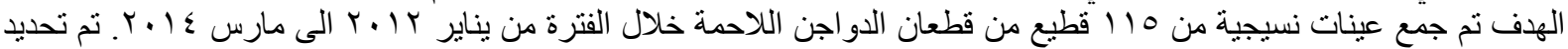
الثفرة الور اثية لجزء من جين الملزن الدموي Hemagglutinin (HA) للتعرف على الثي النمط الجيني المنتشر في المنطقة المستهدفة.

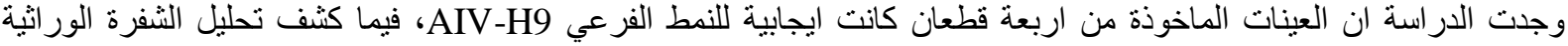

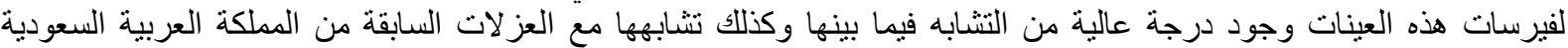

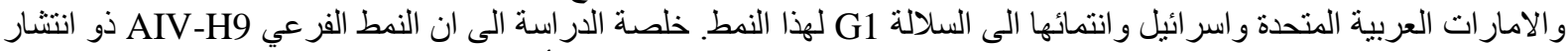

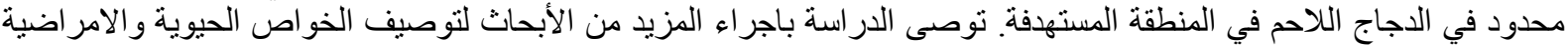

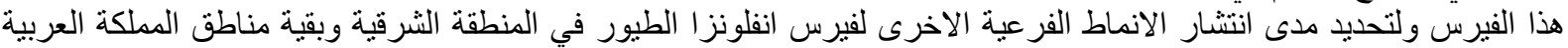

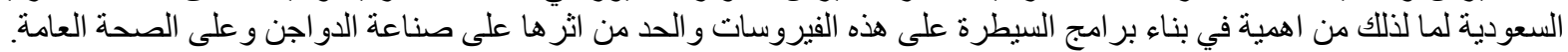

